\title{
Influence of highly dispersed materials on physiological activity of yeast cells
}

\author{
T.V. Krupska, A.A. Turova, V.M. Gun'ko, V.V. Turov
}

Institute of Surface Chemistry NAS of Ukraine General Naumov str., 17, Kyiv, Ukraine, 03164

turova83@inbox.ru

\begin{abstract}
Aim. The influence of two types of colloidal particles, mineral (based on modified nanosilica) and composite (based on starch hydrogels and modified nanosilicas) on the activity of yeast cells was investigated. Methods. The structure of interfacial water layers in the system of yeast cells/nanosilica was studied by NMR spectroscopy in combination with a water freezing technique. Results. It was found that Highly Dispersed Silica (HDS) strongly influences the structure of the interfacial water layers in the dehydrated cells. Conclusions. Modified silica stimulates the vital processes in yeast cells.
\end{abstract}

Keywords: ${ }^{\prime} H$ NMR spectroscopy, hydration, unfrozen water, yeast cells.

Introduction. Recently a great attention has been paid to investigations of interactions of microorganisms with highly dispersed materials capable to influence essentially physiological activity of microbe populations via changes in the intensity and direction of biochemical processes, proliferation rate of microorganisms and biomass growth. In some cases a decrease in the metabolic activity of microorganisms due to their interaction with nanocomposites is of great biotechnological significance since it favors their survival in the anabiosis state [1-3]. However, it is known that physiological activity of microorganisms can be enhanced due to their contact with solid materials [2-4].

The aim of this work was to study an influence of two types of colloidal particles, mineral (modified nanosilicas) and composite (prepared with starch hydrogels and modified nanosilicas), on the vital activ-

(C) Institute of Molecular Biology and Genetics NAS of Ukraine, 2009 ity of suspended Saccharomyces cerevisiae yeast cells, and to analyze the structure of interfacial water layers in a model system "yeast cells - nanosilica "

Materials and methods. Modified silicas were based on highly dispersed silica (HDS) (specific surface area $S=300 \mathrm{~m}^{2} / \mathrm{g}$, pilot plant at the O.O. Chuiko Institute of Surface Chemistry of NAS of Ukraine, Kalush) and silochrome $\left(S=120 \mathrm{~m}^{2} / \mathrm{g}\right.$, "Khimlaborreaktiv" Ltd, Ukraine) modified by aminopropylmethylsilane ("Aldrich", USA) and phosphitic acid ("Aldrich") with approximately one third of silanols substituted with aminopropylmethylsilyl groups. Macroporous $\left(\mathrm{APMS}^{\mathrm{m} \cdot \mathrm{p}}\right.$ ) silochrome and highly dispersed silica $\left(\mathrm{APMS}^{\text {h.d. }}\right)$ with aminopropylmethylsilyl functionalities were synthesized as described elsewhere [5]. One of protons in the amino groups of APMS ${ }^{\text {h.d }}$ was substituted with phosphoric acid residue; i.e. the silica surface was of basic (APMS ${ }^{\text {h.d. }}$ ) or acidic (phosphorus-containing 
silica) character. The concentration of surface functionalities was controlled by element analysis $(\mathrm{C}$, $\mathrm{H}, \mathrm{P}, \mathrm{N})[6]$.

Potato starch ("Khimlaborreaktiv" Ltd, Ukraine) was used as biopolymeric colloidal particles. To create nanocomposites, starch hydrogels (4-50 wt $\%$ of biopolymeric phase) were mixed with HDS at the starch to silica ratios of 9:2, 7.8:1, 1.4:1, 1:1.4, and 1:3. The hydrogels were prepared with careful stirring powder-like components and certain amounts of water. Then the mixture was heated to $87{ }^{\circ} \mathrm{C}$ with intensive stirring.

Yeast cells ("Enzim", Ukraine) were cultivated in $8 \%$ glucose solution (solution for injections, "Farmak", Ukraine) at $28{ }^{\circ} \mathrm{C}$. While analysing yeast cells growth the number of cells was controlled. The solution turbidity and carbonic acid gas elimination depend on the number of cells, that can be estimated according to a known procedure $[7,8]$. The aqueous solution $(0.11)$ containing $8 \%$ of glucose was put in a 0.251 flask, $1 \mathrm{~g}$ of dried yeast was added, and then the flask was blanked with a stopper having a built-in bib. As a result of fermentation, carbon dioxide was formed in the flask and evaporated freely, therefore the mass of the reaction vessel decreased that can be determined quantitatively. Firstly, the flask with a sample was weighed using a VLKT-500 technical balance with accuracy of $\pm 0.01 \mathrm{~g}$. The reaction vessel was weighed periodically to find the weight of $\mathrm{CO}_{2}$ eliminated. The number of cells was counted by means of a microscope in the Goryayev camera. The suspension turbidity was measured trough the optical density using a KFK photocolorimeter at $\lambda=670 \mathrm{~nm}$ and the optical length of $0.1 \mathrm{~cm}$ using a red filter with the maximum of pass band at $670 \mathrm{~nm}$.

To study the characteristics of water in cells and suspension, the ${ }^{1} \mathrm{H}$ NMR spectroscopy with layer-by-layer freezing-out of water was used to record the signal of unfrozen water [10-15]. It is possible to determine thermodynamic characteristics of interfacial water layers using this method since changes in the melting point of ice depend on the surroundings. The ${ }^{1} \mathrm{H}$ NMR spectra were recorded using Varian 400 Mercury (USA) spectrometer of high resolution with the probing $90^{\circ}$ pulses. The temperature was controlled by means of a Bruker VT-1000 device. Relative mean er- rors were $\pm 10 \%$ for [the] ${ }^{1} \mathrm{H}$ NMR signal intensity and $\pm 1 \mathrm{~K}$ for temperature. To prevent supercooling of the studied systems, the measurements of the amounts of unfrozen water were carried out at heating the samples preliminarily cooled to $210 \mathrm{~K}[10,13,15]$. The ${ }^{1} \mathrm{H}$ NMR spectra recorded here include the signals only of nonfreezable mobile water molecules. The signals of water molecules from ice, as well as protons from the materials, do not contribute to the ${ }^{1} \mathrm{H}$ NMR spectra because of the features of measurement technique. The chemical shifts of proton resonance $\left(\delta_{\mathrm{H}}\right)$ of intercellular water were measured in air (with $\mathrm{CHCl}_{3}$ as outer standard, $\delta_{\mathrm{H}}=7.26 \mathrm{ppm}$ ) or $\mathrm{CHCl}_{3}$ medium. Chloroform can dissolve relatively small quantity of water $(<0.6 \mathrm{wt} \%$ at $T<295 \mathrm{~K})$. Therefore one can assume that water dissolved in chloroform does not strongly contribute to the total ${ }^{1} \mathrm{H}$ NMR signal. Noteworthy, that the use of $\mathrm{CDCl}_{3}$ allows us to determine accurately the $\delta_{\mathrm{H}}$ values of bound water, to avoid heterogeneous broadening of the NMR signal and to reduce the molecular exchange between water clusters bound to different active sites [10-15].

Results and discussion The results of measurement of the biometric indices of nanosilica influence on the vital activity of yeast cells are shown in Fig. 1. If a certain amount of yeast cells is an aqueous suspension with fixed quantity of nutritive material (glucose), the growth of yeast cells can be characterized by several stages [9]. The first one is a lag-phase when the cells adjust to a new medium. This stage of development is relatively short and does not exceed a few hours. The second stage is an exponential phase when the growth of colony takes place along with accumulation of cell biomass and steady elimination of gaseous carbon dioxide because of bioactivity of cells. The third one is a stationary phase when the cells colony degrades with decreasing concentration of nutrients and accumulating product of cell metabolism (ethanol). At this stage the body of the cells is destroyed .

For all the systems containing silica similar changes are observed in the curves of gas release and biomass increase. The initial stage of the process (up to $5 \mathrm{~h}$ ) is characterized by proliferation and respiratory activity of the cells, and no lag-phase was registered. Therefore, in the presence of nanosilica the cells adapt extremely quickly to the medium, begin to divide and have great respiratory activity. After $40 \mathrm{~h}$ (in the exponential 

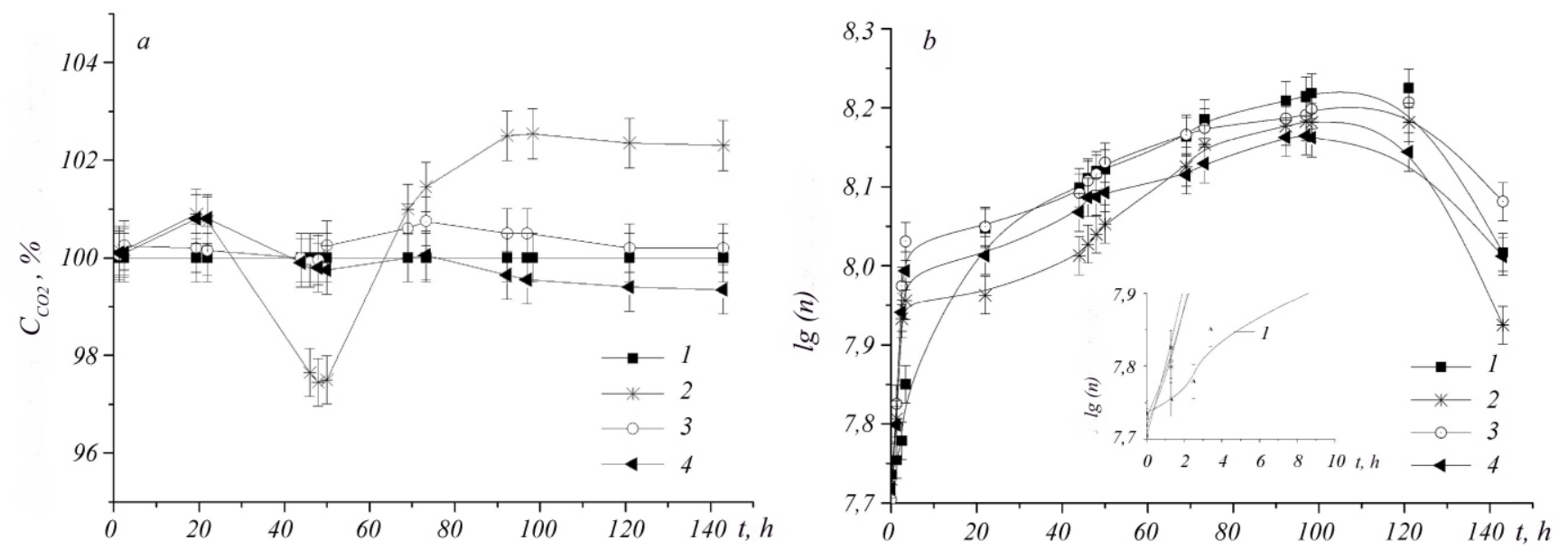

Fig. 1. Dynamics of gaseous carbon dioxide release in the process of yeast fermentation $(a)$ and biomass increase of yeast cells in the presence of modified silicas $(b): 1$ - control; 2 - phosphorus-containing silica; 3 - APMS $^{\text {m.p. }} ; 4$ - APMS $^{\text {h.d. }} ; \mathrm{C}_{\mathrm{CO} 2}$ is the relative concentration of $\mathrm{CO}_{2}$ with respect to the control sample; $\mathrm{n}-$ is the number of cells in $\mathrm{cm}^{3}$.

phase), minimum respiratory activity is evident relative to the control $8 \%$ glucose solution without additions (Fig. 1, $a$ ) which is due to a decrease in the volume of gas release for phosphorus-containing silica (sample 2) despite rather intensive process of cell proliferation (Fig. 1,b). On subsequent incubation of the cell suspension, the gas release increases again and its absolute maximum is for the sample 2 for incubation time of $90 \mathrm{~h}$, which is larger than that for other samples. Then the gas release rate decreases for all the samples because of ethanol accumulation in the solution, the decrease in glucose content, and destroying of a great number of cells.

No stage of relative decrease in intensity of respiratory activity of yeast cells is observed after 30 to $60 \mathrm{~h}$ of incubation as well as for the control sample (suspension of yeast cells in glucose solution). This can be explained by the fact that this stage is conditioned by the presence of silica particles. Both modified and unmodified silicas are characterized by high adsorption capability to biopolymer molecules and cell objects [1-3]. During preparation of samples the silica particles and cells seem to form stable aggregates with structures corresponding to minimal Gibbs free energy of the cells - water - silica system. Just in such aggregates cells can transform from the anabiosis to active functioning. Silica particles can affect the cell adaptability to the medium and promote their quick reproduction. Nevertheless, at biomass growth the cells newly formed change the stability of cell - silica aggregates and they (after reaching some breaking point of the colloidal system) begin to form new aggregates of another composition because of changes in the state and thermodynamic parameters of the colloidal solution. The respiratory activity of cells can slow down when they lose contacts with the surface corresponding to the minimum in the $m_{\mathrm{CO} 2}$ $(t)$ plot (Fig. 1, $a$ ). When the suspension rearranges to the end, the cell respiratory activity increases again and can exceed the initial one because of interaction with mineral particles.

It should be noted that the curves of gas release and biomass growth do not coincide. Thus, in the presence of nanomaterials the number of cells decreases as compared to that in the control sample whereas their respiratory activity increases. Thus nanodispersed materials are capable to intensify essentially the vital processes of cell cultures and to enlarge the rate of glucose reprocessing without any considerable effect on the rate of cell division. It is the most evident for the phosphorus-containing sample that is probably conditioned by its acidic properties.

In order to confirm the assumptions stated, the effect was examined for nanocomposites prepared on the basis of silicas and starch gels affecting the vital activity of yeast cells. Starch can form stable biocolloidal systems with silicas (silica core- starch shell particles) [16], therefore it can be expected that biocomposites with cells can form complex aggregates in the suspen- 

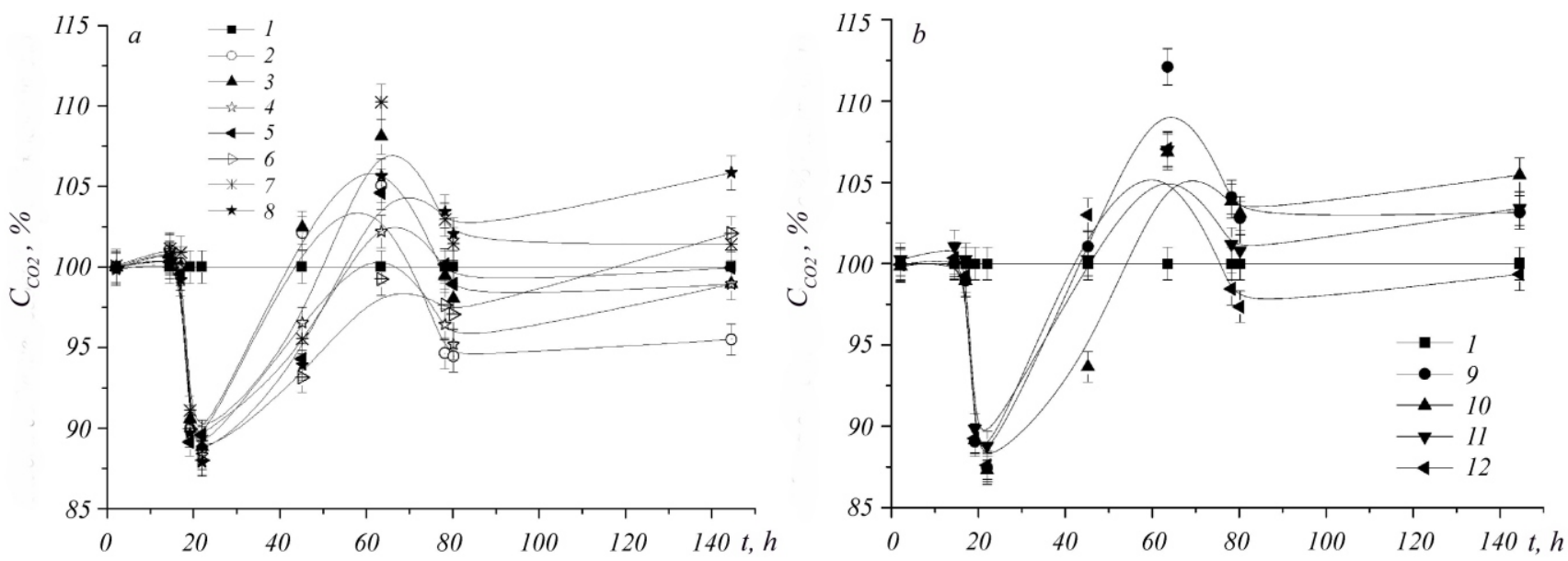

Fig. 2. Dynamics of $\mathrm{CO}_{2}$ release in the fermentation process in the suspension of yeast cells with additions: 1 - control; 2 - starch (7,8): HDS (1): water (138.8); 3 - starch (7,8): HDS (1): water (72); 4 - starch (7.8): HDS (1): water (12.2); 5 - starch (1): HDS (3): water (30); 6 - starch (1): HDS (1.4): water (20); 7 - starch (1.4): HDS (1): water (14); 8 - $\operatorname{starch}(4.5)$ : HDS (1): water (16); 9 - starch (1): APMS h.d. (3): water (30); 10 - $\operatorname{starch}(1): \operatorname{APMS}^{\text {h.d. }}(1.4)$ : water (20); $11-\operatorname{starch}(1.4)$ : $\operatorname{APMS}^{\text {h.d. }}(1)$ : water (14); 12 - $\operatorname{starch}(4.5)$ : $\operatorname{APMS}^{\text {h.d. }}$ (1): water (16).

sions. In these composites cell membranes should contact with the biopolymer shells of mineral particles rather than with the silica cores, i.e., direct cell-silica contacts are prevented at the initial stages of incubation.

Fig. 2 shows the effects of starch hydrogel with silica admixtures on gas release of yeast cells. Coverage of mineral particles with the biopolymer shells results in reduction of cell adaptation to the culture medium. Nevertheless a total quantity of $\mathrm{CO}_{2}$ formed in the samples studied exceeds the control value by $15-30 \%$ that testifies to the stimulating effect of nanooxides on the vital activity of yeast cells in these samples (see Table). A section of the kinetic curves related to the reorganization of the colloidal system remains for these samples (as for that with silica but without starch) due to accumulation of cells biomass followed by a relative decrease in their respiratory activities. The stage of cell colony degradation is displaced towards longer time and is not observed at chosen incubation duration (140 h).

Bionanocomposites of any type have a stimulating impact on the cell fission in contrast to the initial oxides (Table). The maximum biomass growth (29-33\%) is observed for highly dispersed with the aminoprpylmethylsilyl groups (Table, samples 14 and 15). Changes in the concentration ratio between mineral and biopolymeric components in the nanocomposites do not result in systematic variation of their biological activities. However it was shown previously [16] that this ratio can strongly influence the conformational state of starch macromolecules. Probably, the stimulating action of nanosilicas on yeast cells occurs if the starch molecules are displaced by the cells at the silica surface, and the conformational state of starch molecules becomes insignificant.

To elucidate possible reasons of the stimulating action of silicas on the yeast cell vital activity, the effects of nanosized particles on water state within the contact zone were studied in the model system with highly dispersed silica - yeast cells because such interactions can result in considerable changes in the cell metabolism.

The ${ }^{1} \mathrm{H}$ NMR spectra of water in partially dehydrated yeast cells (Fig. 3, $a, b-$ samples 1 and 2, respectively), silica powder (prepared by drying aqueous suspension) containing $4 \mathrm{wt} \%$ of bound water (Fig. 3, $c$, sample 3), and the composites consisting of a dried mixture of yeast cells and silica $(2: 1)$ including various quantities of bound water (Fig. 3, $d-f$, samples $4-6$ ) were detected.. The measurements were carried out in a weakly polar chloroform medium which considerably reduced the NMR signal width and allowed us to determine the chemical shifts of protons in bound water, as well as to stabilize the water state both in yeast cells and at the interface of cell - highly dispersed silica particles.

The water signals in yeast cells (Fig. 3, $a, b$ ) containing 11 to $27 \mathrm{wt} \%$ of water are observed as a single 


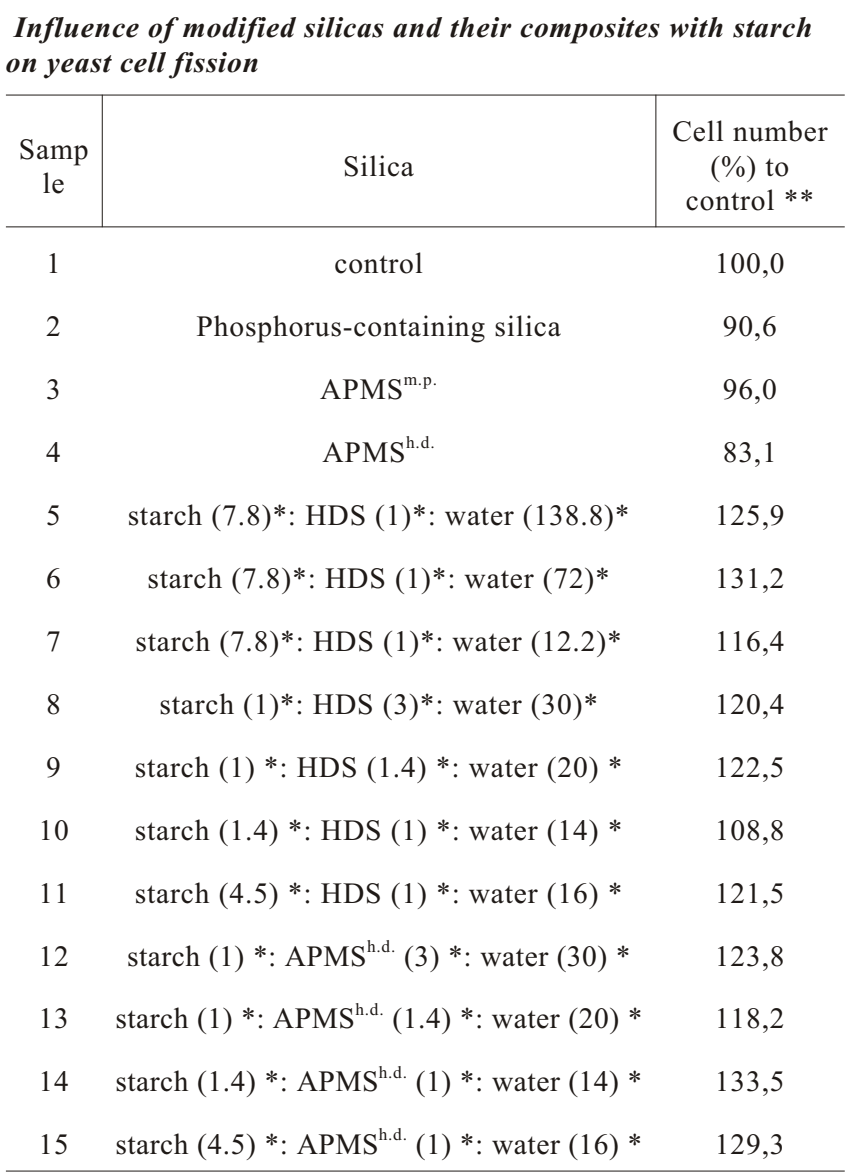

*Weight ratio of components;

** control sample corresponds to the suspension of cells in the $8 \%$ solution of glucose.

signal at $\delta_{\mathrm{H}} \approx 1.3 \mathrm{ppm}$. All water in cells is bound, i.e. it undergoes a strong disturbing effect of the surroundings, which correspond to the surface of structural elements inside cells and biopolymeric substances transformed to the solid state on dehydration. The chemical shift of protons in the interfacial water is controlled by the number of hydrogen bonds per a water molecule as well as by the strength of the hydrogen bonds for water-water and water-surface functionalities.

Taking into account the fact that the number of water-water hydrogen bonds can be more than that of water-surface ones ( each water molecule can form four hydrogen bonds) and the strength of these bonds almost does not differ, one can assume that the chemical shift of protons in water is controlled, first of all, by the coordination number of water molecules [10-12]. If the latter changes from 0 to 4 , the $\delta_{\mathrm{H}}$ value changes from 1.3 to
7 ppm [12]. Thus intracellular water is weakly associated (each water molecule forms less than one hydrogen bond as proton-donor) or characterized by strongly disturbed hydrogen bond network.

A few signals are observed in the ${ }^{1} \mathrm{H}$ NMR spectra of the silica powder (prepared by drying of the aqueous suspension) containing about $4 \mathrm{wt} \%$ of water (in deuterochloroform medium). The signal from strongly associated water adsorbed on silica surface at $\delta_{\mathrm{H}}=$ 4.2-4.8 ppm is the most intensive. The $\delta_{\mathrm{H}}$ value testifies that each water molecule takes part in the formation of 2.5 hydrogen bonds on average. This is the water with partially destroyed ice-like structure typical for both liquid water and most of biological objects containing bound water. The signals at $\delta_{\mathrm{H}}=7.26 ; 5$, and $1.3 \mathrm{ppm}$ are linked to the protons in $\mathrm{CH}$ groups of non-deuterated chloroform present as an admixture, $\mathrm{OH}$ groups of water in nanodrops dispersed in the chloroform phase or weakly-associated water, respectively.

For the composite systems containing cells and silica (Fig. 3, $d$-f) dehydrated under the same conditions as silica suspension (its spectrum is shown in Fig. 3,c) at $C_{\mathrm{H} 2 \mathrm{O}}=12 \mathrm{wt} \%$, more than $90 \%$ of the total quantity of bound water belongs to weakly associated one. Nevertheless, unlike the sample 1 (Fig. 3, a), when fixed water quantities are added to the sample 3 (Fig. 3, $b$ ), an intensive signal of strongly associated water is registered at smaller concentration of bound water than it takes place for partially dehydrated cells (Fig. 3, b,e,f). In the sample 5 (Fig. $3, e$ ) above $30 \%$ of water is weakly associated whereas in the sample 6 (Fig. 3,f) above $20 \%$ of the total quantity of bound water is weakly associated.

Thus, HDS strongly influences the structure of interfacial water layers in partially dehydrated cells. When silica nanoparticles contact with cell surface not only a decrease in concentration of bound water takes place caused by cell-surface interactions [10], the displacement of boundary water and dehydration of both surfaces, but also the changes in the structure of interfacial water. The most part of water localized at the cell-silica interface transforms from strongly associated water to weakly associated one. Therefore, silica particles at the cell surfaces can strongly influence the penetrability of the cellular membranes since weakly associated water presents a weak barrier for both polar and non-polar substances and promotes the cellular metabo- 

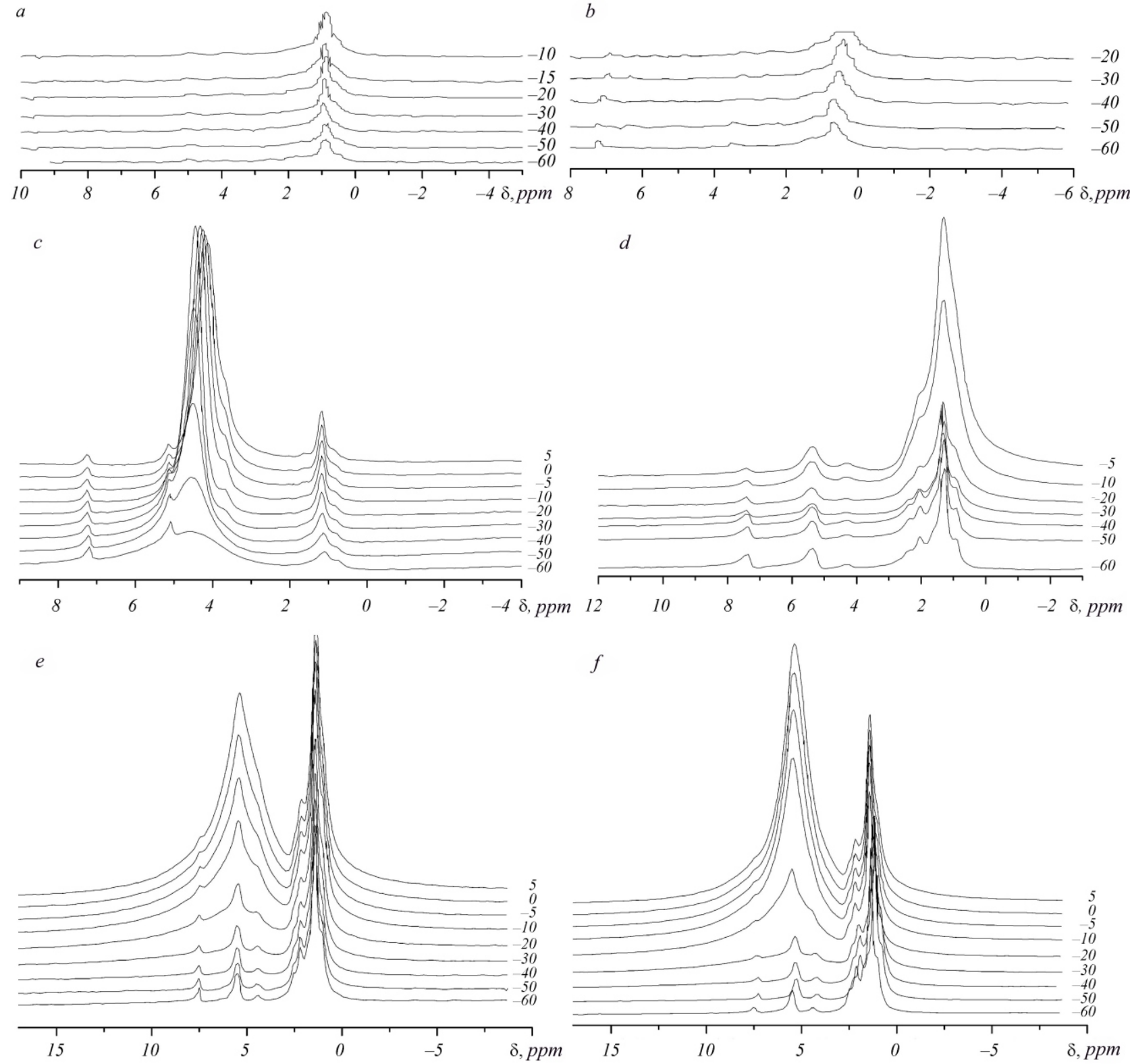

Fig. 3. ${ }^{1} \mathrm{H}$ NMR spectra of water bound in $(a, b)$ partially dehydrated yeast cells; $(c)$ silica powder prepared by drying of the aqueous suspension; $(d-f)$ dehydrated composites at cells: silica $=2: 1$ at different content of water.

lism processes. This activates the vital functions of the cells and results in strengthening gas release and biomass growth observed experimentally.

Reasoning from the results obtained, one can draw a conclusion on the considerable stimulating influence of modified silicas and related nanocomposites on the vital activity of Sac.cerevisiae yeast cells. The mechanism of this effect is quite complicated. It is conditioned, to all appearance, by the transition of the water-organic systems located at the cell-silica interfaces into a cluster state characterized by the presence of weakly associated water. This is a peculiar state of the material where interfacial water becomes easily permeable for both polar and non-polar organic substances that promotes the cellular metabolism processes. Nevertheless, despite the respiratory activity of cells increases in case of the use of both nanosilica and related nanocomposites, the reproductive performance of cells increases only at utilizing starch-silica nanocomposites. 
Thus, application of bionanostimulators gives an opportunity to control different aspects of cellular metabolism directed to both cell biomass growth and intensification of the fermentation process. These properties of nanosized biostimulators can be utilized in various biotechnological processes.

\section{Т. В. Крупская, А. А. Турова, В. М. Гунько, В. В. Туров}

Влияние высокодисперсных материалов на физиологическую активность дрожжевых клеток

Резюме

Цель. Изучить влияние на жизнедеятельность суспензии дрожжевых клеток Saccharomyces cerevisiae двух типов коллоидных частиц-минеральных (модифицированных нанокремнеземов) $u$ композитных (приготовленных на основе гидрогелей крахмала и модифицированных нанокремнеземов). Методы. В модельной системе дрожжевые клетки-нанокремнезем с использованием ${ }^{1}$ Н ЯМР спектроскопии в сочетании с методикой вымораживания жидкой фазы исследована структура межфазных слоев воды. Результаты. Установлено, что высокодисперсные материаль существенно влияют на строение переходных слоев воды в дегидратированных клетках. Выводы. Модифицированные кремнеземы стимулируют проиессы жизнедеятельности дрожжевых клеток.

Ключевые слова: 'Н ЯМР спектроскопия, гидратированность, незамерзающая вода, модифищированные кремнеземы, суспензии дрожжевых клеток.

\section{Т. В. Крупська, А. А. Турова, В. М. Гунько, В. В. Туров}

Вплив високодисперсних матеріалів на фізіологічну активність дріжджових клітин

Резюме

Мета. Вивчити вплив на життєдіяльність дріжджових клітин Saccharomyces cerevisiae двох типів колоїдних частинок - мінеральних (модифікованих нанокремнеземів) $і$ композитних (приготовлених на основі гідрогелів крохмалу та модифікованих нанокремнеземів). Методи. У модельній системі дріжджові клітини-нанокремнезем з використанням ${ }^{I} \mathrm{H}$ ЯМР спектроскопіі у поєднанні з методикою виморожування рідкої фази досліджено структури міжфазних шарів води. Результати. Встановлено, що високодисперсні матеріали істотно впливають на будову перехідних шарів води в дегідратованих клітинах. Висновки. Модифіковані кремнеземи стимулюють прочеси життєдіяльності дріжджових клітин.

Ключові слова: 'Н-ЯМР спектроскопія, гідративність, незамерзаюча вода, модифіковані кремнеземи, суспензії дріжджових клітин.

\section{REFERENCES}

1. Medical chemistry and clinical use of silicon dioxide / Ed. A. A.Chuiko.-Kyiv: Naukova dumka, 2003.-415 p.

2 Kurdish I. K., Bichtunov V. L., Tsimberg E. A., Elchits S. V., Vigovskaya E. L., Chuiko A. A. Effect of dispersed silicon dioxide - Aerosil A-300 on the gowth of yeast Saccha omyces cerevisiae // J. Microbiol.-1991.-53, N 2.-P. 41-44.

3. Kurdish I. K., Kigel N. F. Effect of high-dispersed maerials on physiological activity of metanotrophic bacteria's // J. Microbiol.-1997.-59, N 2.-P. 29-36.

4. Zviyginzev D. G. Soil and microorganisms.-Moscow: Moscow State Univ. press, 1987.-246 p.

5. Turova A. A., Gun 'ko V. M., Turov V. V., Gorbik P. P. Influence of structural and chemical modification of silica on its surface hydration // Adsorb. Sci. and Technol.-2007.25, N 1-2.-P. 65-69.

6. Klimova $V$. A. Fundamental micromethods of analysis of organic compounds.-Moscow: Chemistry, 1975.-224 p.

7. Microbiology Large workshop / Ed. G. L. Selibera.-Moscow: Vysshaya shkola, 1962.-503 p.

8. Microbiology workshop Ed. N. S. Egorova.-Moscow: Moscow State Univ. press, 1976.-307 p.

9. Teulor D., Green N., Staut U. Biology.-Moscow: Mir, 2002.Vol. 1.-436 p.

10. Gun'ko V. M., Turanskaya S. P., Nechipor O. V., Ukchimenko E. V., Turov V.V., Chuiko O. O. Weakly associated water in biological objects and at silica interfaces // Chemistry, physics and technology of surface.-Kyiv: Naukova dumka, 2006.-P. 397-430.

11. Turov V. V., Gun'ko V. M., Bogatyrev V. M., Zarko V. I., Gorbik S. P., Pakhlov E. M., Leboda R., Shulga O. V., Chuiko A. A. Structured water in partially dehydrated yeast cells and at partially hydrophobized fumed silica surface // J. Coll. Interface Sci.-2005.-283, N 2.-P. 329-343.

12. Gun'ko V. M., Turov V. V., Bogatyrev V. M., Zarko V. I., Leboda R., GoncharukE. V., Novza A. A., Turov A. V, Chuiko $A$. $A$. Unusual properties of water at hydrophilic/hydrophobic interfaces // Adv. Coll. Interface Sci.-2005.-118, N 1.P. $125-172$.

13. Gun'ko V. M., Zarko V. I., Turov V. V., Voronin E. F., Mironyuk I. F., Chuiko A. A. Structural and adsorptive characteristics of fumed silicas in different media, in: colloidal silica: fundamentals and applications / Ed. H. E. Bergna.- Salisbury: Taylor \& Francis LLC, 2005.-P. 499-530.

14. Turov V. V., Gun 'ko V. M., Zarko V.I., Leboda R., Jablonski M., Gorzelak M., Jagiello-Wojtowicz E. Weakly and strongly associated nonfreezable water bound in bones // Coll. and Surfaces.-2006.-48, N 2.-P. 167-175.

15. Turov $V$. V., Leboda R. Application of H-1 NMR spectroscopy method for determination of characteristics of thin layers of water adsorbed on the surface of dispersed and porous adsorbents // Adv. Coll. Interface Sci.-1999.-79, N 2-3.-P. 173-211.

16. Turov V. V., Novza A. A., Leboda R., Scubichevska-Zieba Y., Schesniyk M., Turov K. V. Bound water in starch hydrogels with highly dispersed silica // Probl. Cryobiol.-2005.-15, N 4.-P. 636-644. 